\title{
RESEARCH ARTICLE \\ DIGITAL LITERACY IN THE ENGLISH CURRICULUM: MODELS OF LEARNING ACTIVITIES
}

\author{
Banatul Murtafi'ah ${ }^{1 *}$, Nur Hidayanto Pancoro Setyo Putro² \\ ${ }_{1,2}^{1,2 n g l i s h}$ Education Study Program, Graduate School Yogyakarta State University, Indonesia \\ *Corresponding Author Email: banatulmurtafiah@gmail.com
}

This is an open access article distributed under the Creative Commons Attribution License, which permits unrestricted use, distribution, and reproduction in any medium, provided the original work is properly cited.

\section{ARTICLE DETAILS}

Article History:

Received 15 July 2019

Accepted 19 August 2019

Available online 23 August 2019

\section{ABSTRACT}

In this era of information, communication, and technology, digital literacy is a must for the internet users including students. Digital literacy means the abilities to both select information on the internet and is aware of online safety. Despite the concerns about digital literacy, there is a paucity in the curriculum which does not state it as a learning goal. Therefore, this paper attempts to propose two models of learning activities to promote teaching digital literacy in an English classroom. After referring to several theories related to digital literacy and text types stated in Indonesian recently used curriculum, two models for teaching English at a senior high school level that promote digital literacy teaching are offered. The models comprise approaches to teach digital literacy, grades, text types, objectives, steps of learning activities, and assessments to assess students' learning.

\section{KEYWORDS}

Digital literacy, English, learning activities.

\section{INTRODUCTION}

Digital literacy has emerged as an essential issue in this era of information, communication, and technology (ICT hereafter). With the growing trend of the internet which offers abundant information, internet users, including students need the ability to be digitally literate. A digitally literate person is someone who possesses the ability to search for information effectively, compares it with a wide range of sources, and categorizes it into reliable and non-reliable information [1]. The ability to be selective in choosing the right information is essentially needed to filter the spread of fake news or hoax and hate speech since the spread of fake news in is now quite massive in Indonesia. According to the report in https://kominfo.go.id/, the official website of the Ministry of Communication and Informatics of the Republic of Indonesia, in 2016, a police cybercrime unit has blocked around 300 social media and websites for spreading fake news or hoax [2]. Furthermore, being digitally literate also means being aware of online safety while browsing the internet [3]. Due to the increase of cybercrime in Indonesia, according to the report for The Jakarta Post, i.e. with the number of cases growing by 389 percent in 2014 to 2015 the need of students to be digitally literate in terms of internet safety is presumably urgent [4].

In relation to its definition, some experts limit the term digital literacy to the context of information only while some others define it in a broader context. Digital literacy nowadays mostly concerns with the skill to gain information [5]. In addition, digital literacy is also defined as the skill owned by a person to grasp and use information in many types of formats from a number of sources obtained through computers [6].

On the other hand, there is another view that puts the term digital literacy in a broader context. The context, which is online safety, has been developed related to digital literacy [5]. This is supported by the digital literacy model that puts online safety or cyber safety as one intersected aspect between cognitive and social-emotional dimensions [3]. The issue of online safety as a part of digital literacy also covers other broader issues such as cyberbullying, safe social networking, healthy digital behaviours, pornography, sexting, privacy, and online reputation [7]. Therefore, the term digital literacy in this paper covers the two issues, namely the ability to search valid and reliable information and the awareness to be safe while being online.
The aforementioned aspects related to digital literacy, i.e. information and online safety, are both important especially for kids and/or adolescents. According to the recent study from Stanford University, $82 \%$ of adolescents cannot select which information is real and which one is fake [8]. Teens also tend to be emotional, then, as a result, they will easily spread information without confirming its credibility, as stated by Wisnuhardana, the Head of Social Media Management Center for Kompas [9]. Teens also tend to have less awareness in relation to online safety. Reports collected from several sources show that (1) most of teens are unconcerned about the dangers of sharing personal information online; (2) more than half of teens (58\%) think that posting photos or other personal information on social networking sites is safe; (3) nearly half of teens $(47 \%)$ are not worried about others using their personal information in ways they do not want; and (4) about half (49\%) are unconcerned about posting personal information online might negatively affect their future [10]. The data show how teenagers nowadays are not really aware of their safety in an online world. Therefore, digital literacy teaching to this generation is needed.

Despite the concerns of digital literacy, there is a paucity of digital literacy in the Indonesian curriculum. There is no explicit statement in both basic and core competencies in the curriculum about teaching digital literacy. However, it seems that the awareness of embedding digital literacy in the school curriculum has increased. One example is an article in a governmental website, i.e. http://pustekkom.kemdikbud.go.id/, that promotes the importance of digital literacy to combat internet hoax by offering ideas to implement digital literacy in the school curriculum [11]. Therefore, an adjustment to the curriculum for school level is probably needed here.

One of the adjustments of the curriculum in which digital literacy teaching can be applied is through English lessons. The reason why English is chosen is that it has become the main language of some areas including technology. Even, eighty percent of the world's electronically stored information is in English and, of the estimated 200 million users of the internet, some thirty-six per cent communicate in English [12]. As a result, English is used as the main language on the internet. Therefore, the adjustment in the English subject is presumably needed. It is supported by the statement stating that English teachers must embrace a new role, advocate for digital literacy in their teaching. English teachers, especially those who teach senior high school students, could probably adjust the 
English curriculum at the school level [13]. Digital literacy can be embedded in the English class through its core and basic competencies stated in the curriculum. For example, while teaching news item texts to the students, the teacher at the same time could possibly teach them how to anticipate with a hoax or fake news. Another example is when teaching procedure texts in the form of tips, the teacher could also teach digital literacy by providing a model text in the form of online safety tips. As information in digital literacy is presented via computers, the texts taught to the students are presented via digital devices. The ideal classroom models for teaching digital literacy could possibly cover some models such as blended, flipped, and/or hybrid learning [14]. Therefore, the digital literacy teaching in the Indonesian education context which is embedded in the English lesson is feasible.

To do so, this paper offers an idea of incorporating digital literacy in English classrooms. This is a non-research paper which is written based on relevant theories to teach digital literacy in the English lesson context.

\subsection{Defining Digital Literacy}

There is a relatively huge body of literature that is concerned with the definition of digital literacy. An early definition restricted the definition of digital literacy in terms of technical aspects of operating digital devices [15]. Recently, several experts provide a broader definition of digital literacy. It is defined as much more than an individual's ability to handle computers. It deals with how an individual applies it in the context of cognitive and socio-emotional aspects of work in a computer environment [3],[5],[16]-[17]. Similarly, a digital literacy is also defined as an ability that covers "the skills and ability to use digital tools applications; the capacity to critically understand digital media tools and content; and the knowledge and expertise to create and communicate with digital technology" [14]. This paper, therefore, follows the definition of digital literacy with the more recent views which state that digital literacy covers the cognitive, socio-emotional and technical abilities to use digital technologies.

From the aforementioned definition, the dimensions of digital literacy are derived. The dimensions of digital literacy are divided into three intersecting dimensions, namely (1) technical, (2) cognitive, and (3) social-emotional dimensions [3]. Within the cognitive dimension, there are two types of literacy that probably could be implemented in teaching and learning namely information literacy and critical literacy. Meanwhile, there is also an intersected aspect between cognitive and social-emotional dimension, namely cyber safety, or later will be known as online safety throughout this paper. Hence, the term digital literacy in this paper specifically focuses on the information literacy, critical literacy, and online safety. This paper, however, will not consider the technical skills of operating digital devices as its objective. After defining the term of digital literacy, the next discussion will be about how to implement it in the classroom.

\subsection{Approaches to Digital Literacy Education}

Regarding how digital literacy will be implemented in the classroom context, [14] offer three approaches to the digital literacy education, namely: an infusion, integration, and dispersion. The infusion approach states that the present-day students cannot successfully collect information, create, or learn without the use of digital devices [14]. Therefore, in this approach, the students will practice their literacy skills such as reading and writing supported by the use of ICT. The integration approach emphasizes on the principle that "ICT should be used whenever appropriate to facilitate learning" [14]. In this approach, there is a combination between ICT and other subjects. Therefore, the outcomes of the learning do not only cover the ability to master the subject areas but also the ability to use the ICT. Furthermore, in the dispersion approach, students majoring in languages or arts, for instance, are provided with digital texts and media. Therefore, aspects of digital literacy are comprised of the language and media literacy curriculum. As the writer will not include the students' technical skill in operating ICT devices, the integration approach does not meet the writer's objective of this paper. Thus, the most feasible approaches to apply are probably infusion and/or dispersion approaches. After discussing the approaches, how digital literacy will be delivered is subsequently discussed.

\subsection{Models of Delivery in Teaching Digital Literacy}

Digital literacy teaching and learning can be applied to some models of learning with technology such as blended learning, flipped learning, and hybrid learning [14]. The model of blended learning in the classroom refers to the place where learning happens, a combination of both face-toface learning and online learning [18]-[19]. Some examples in relation to the classroom condition for blended learning include the availability of learning management systems offering online courses that can be accessed by the students and thus allow those from remote areas to access online learning [14].

The next model, flipped learning, focuses on the use of digital devices by the students outside the classroom, such as home, and discuss what they have done at home together with other friends and their teacher in the classroom [14]. In this type of learning, some of the content of learning is done outside school hours which however can possibly burden the students with those out-of-school tasks. One of the examples of flipped learning in mathematics class includes students who are asked to watch a tutorial video containing materials as preparation before going to the next meeting in the classroom [20]. Then, in the class, the teacher asks them to solve the calculus exercises based on the materials they watch in the video.

Furthermore, the last model is a hybrid learning model. The hybrid model is often confused with the blended learning model as both of them combine face-to-face and online classroom. The difference is on the proportion of face-to-face learning and online learning [14]. In hybrid learning, students focus on communication with their friends and teacher during the face-to-face learning in the classroom, meanwhile, they use digital tools for individual learning. Based on the discussion on the models used for teaching digital literacy, it seems that blended and hybrid models could possibly be conducted for the context established in this paper. The flipped model is not really appropriate since the writer focuses the learning activities on the classroom, not at home. Within these models of delivery, several learning activities that promote digital literacy are proposed.

\subsection{Types of Learning Activities to Promote Digital Literacy at School}

The learning activities for promoting digital literacy can be categorized into four broad activities, namely: producing media, gaming, coding, and making [14]. In producing media, students produce their own digital artefacts in which the learning process occurs through this process. Some examples of producing media activities include blogging, microblogging, video blogging (vlog), podcasting, graphic novels and comic strips, and digital storytelling [14]. Blogging is an activity in which the students write their opinions or ideas using safe, secure, and supported blogging sites. Microblogging, as its name suggests, includes sharing ideas using short and simple statements or even pictures. The text produced in microblogging is much shorter than in blogging. The digital tools that can be used for microblogging are also known as social media, such as Twitter, Tumblr, Instagram, or Snapchat.

Another example of producing media activity is now becoming a trend among young people, i.e. vlog or video blogging. Through vlogs, students may present oral speeches in the form of videos demonstrating skills that have been mastered [14] and upload it to video websites such as YouTube. Podcasting is another learning activity for producing media. In podcasting, students record their voice and present their ideas or opinions on something. It is different from vlog in which podcasts are in the form of audio only. Therefore, students' voice is the main product of this activity. In podcasting, students are also able to add some other sounds as background [14].

Graphic novels and comic strips are some other producing media activities. Teachers may provide digital comics or novels and ask the students to read them for reading activities. Students may also use comic strip maker applications such as Bitsrips, Pixton, or Comic Creator to create their own comics based on their own stories and creativities.

The last producing media activity is digital storytelling. Digital storytelling includes not only audio but also visual components as its features [14]. Through the digital storytelling software provided on its website, $\mathrm{http} / / /$ digitalstorytelling.coe.uh.edu/, students can produce their own stories. Finally, in relation to the ideas for promoting digital literacy in the English classroom, all learning activities in producing media activity are plausible to be applied.

The three other activities include gaming, coding, and making [14]. The term gaming in this context is defined as playing a game as an activity to promote digital literacy. Video gaming is now increasingly considered as a new literacy so that games such as Angry Birds or mapping with Minecraft offer chances for students to engage in digital literacy [14]. The next activity is coding which deal with coding web languages such as HTML and Java. In this activity, students learn to build simple programs and/or games. Another activity is making - the 'maker movement' which allow the students to make things or projects that are related to events such as robotics, cardboard box creation, and others. 
Among these four activities, i.e. producing media, gaming, coding, and making, the one that is most appropriate for learning activities in the context of this paper is producing media activities. The other three seem to be inapplicable as they are perhaps related more on technical things with ICT and science. Therefore, this throughout this paper, the learning activities to promote digital literacy focus only on the producing media learning activities. These learning activities are then adjusted and embedded in the English curriculum in the Indonesian school contexts, specifically for a secondary level.

\section{METHOD}

This is a literature-based paper in which the authors did not conduct any empirical research. Instead, the authors refer to several theories related to digital literacy mentioned previously such as approaches to digital literacy education, models of delivery in teaching digital literacy, types of learning activities to promote digital literacy, and also text types specified in the Indonesian recently used curriculum.

\section{RESULTS AND DISCUSSION}

The idea of teaching digital literacy in this paper refers to the implementation of the learning activities for an English classroom. After referring to several theories in the previous discussion, the author proposes some models of learning activities to be applied to an English subject. The approach of teaching digital literacy chosen by the author includes infusion and/or dispersion with the use of ICT. With those approaches, the models of hybrid and/or blended learning in which the learning process is supported with ICT and are conducted in both face-toface and distance learning [14]. Therefore, regarding some text types stated in the English curriculum, two models of learning activities for teaching senior high school students that promote digital literacy teaching are derived. The models consist of the explanation of the approach used, the model of delivery, the types of learning activities, the types of text, grade, learning goals and objectives, and teaching procedures. The two models proposed in this paper focus on two aspects of digital literacy, i.e. information and online safety.

\subsection{First Model of Learning Activities}

Considering the facts that more than $80 \%$ teenagers failed to differentiate fake news and real news [8], the first model emphasizes the importance of being digitally literate in distinguishing real news and fake news. It aims to teach news item texts for grade XII senior high school, based on the competencies in Curriculum 2013. This model focuses on the teaching for receptive language skills, i.e. listening and reading as the basic competencies stated in the curriculum [21]. Students in this model are expected to both comprehend news item text and distinguish between real news and fake news. Both infusion and dispersion approaches are appropriate for this model. Both microblogging and video blogging (vlog) activities can possibly be applied to this model. The model can be conducted in two meetings with exact proportion of face-to-face learning and distance learning.

The procedures, which are adapted from https://resourced.classflow.co.uk/ with some modification, are explained as follow. The first meeting is face-to-face learning in the classroom starting with the teacher brainstorms about fake news. The teacher may ask some questions about fake news such as: (1) what is fake news? (2) where do you find fake news? (3) have you ever shared one? (4) when have you shared it? (5) why is it important if we cannot distinguish real news from the fake news? (6) where do you get your news? and (7) is it trustworthy? and so on. After building the students' awareness of the fake news, the teacher then provides them with the indicators that a news text is a fake one. Tell the students that fake news usually: (1) is written in capitals in the headline, (2) promises to tell something that other media do not want others to know, (3) comes with the content that does not support the headline, and so on. In the first meeting, the teacher may provide students with real news and fake news. The examples may be in the form of written, audio or, audio-visual news. The teacher leads the discussion about the examples, why they are real, and why they are fake. Then, at the end of meeting 1 , the teacher asks the students to work in pairs, browse some real and fake news in English, and discuss the reasons.

In the next meeting, students are asked to bring the tasks from the previous meeting. Each pair is asked to present the result of their tasks while others and the teacher may give comments on it. In this meeting, the teacher can either ask the students to bring their own laptop or conduct the teaching and learning process in the computer laboratory to access the internet. After reviewing the results from all pairs, the teacher then presents the materials about news item text and its structures. The teacher encourages the students to check once again whether their version of real news can be categorized as a news item text or not. The students are also encouraged to find the other news item in the form of written, audio, or video from the internet. At the end of the meeting, the students are given the assignment to work individually and reflect on what they have learned about fake news and real news. The reflection must be posted on their social media, such as Instagram, Facebook, or Twitter. The summary also attaches an example of real news and an example of fake news. The teacher monitors this assignment, gives comments on every student's post, and encourages the others to put some comments on each other posts as well. The teacher needs to emphasize that every post and comment must be written in English.

Not only formative and summative assessment, but also self-assessment can be done through this model. The formative assessment is conducted to see the process of students learning while the summative can be done after the students finishing the tasks [22]. Furthermore, the selfassessment is possible to be conducted in the last assignment in which each student is asked to reflect on what they learned. After focusing on the model related to awareness of the credibility of information, the next model will discuss the other important part of digital literacy namely online safety.

\subsection{Second Model of Learning Activities}

The second model focuses on building students' online safety awareness. This concern is derived from the data mentioned that teenagers have less awareness in relation to online safety [10]. As this model follows the framework from Curriculum 2013, it aims to teach procedure texts in the form of tips for grade XII senior high school students. This model, which covers the four skills of language learning, i.e. listening, reading, writing, and speaking, employs project-based learning method as suggested in Curriculum 2013 [21]. Students throughout the activities in this model are expected to create an online poster containing tips for staying safe while being online or connected to the internet. Since this is a project-based learning, therefore, there should be at least two or three meetings to teach this model as it consists of several stages [23]. Both infusion and dispersion approaches can possibly be used for this model. The notion that these approaches bring, i.e. using digital devices for learning seems appropriate to be applied here [14]. The model of delivery can be both face-to-face learning and distance learning. Microblogging and video blogging (vlog) are the learning activities proposed in this model.

The following procedures can be done by the teacher to teach the second model. The first meeting is in the form of face-to-face learning in the classroom. In this meeting, the teacher conducts warming-up activities by showing the icon of social media and asks how many students use those social media. The teacher then provides listening activity through a video containing online safety tips and asks the students to answer the questions related to the video. In the reading activity, students, in groups, are given a model of an online safety poster. The teacher also provides several exercises to prepare them for writing their own tips. The teacher, later on, explains that the students must work in groups consisting of three to four people to create a project in the form of an online safety poster. The mechanisms of the project, such as schedule and duration, are discussed afterward.

The next meeting is also a face-to-face learning in which students work with their own groups focusing on their own poster. They are allowed to access any source of information to complete their posters. The teacher works as a facilitator in which she or he gives the suggestion for the improvement to each group. In this meeting, the teacher tells the students that they must upload the posters in their own social media (microblogging), such as Instagram, Twitter, Facebook, and so on. Each group is also required to present their posters in the form of video blogging. The teacher gives two options whether each group makes a short video presenting their posters or conducts a live streaming through their social media. Both can be done through social media such as YouTube, Instagram, or Facebook. The other students including the teacher will comment on the post and the video or live streaming of a certain group. The moment in which all the class members meet virtually within social media is considered as the third meeting. Therefore, this meeting is also categorized as a distance learning.

The assessment for this model may cover formative, summative, and selfassessment. The teacher can assess the process of students learning during the face-to-face learning. The formative assessment can also be done using the tasks or exercises given at the beginning of the meeting. Meanwhile, the summative assessment can be done during the distance learning. The teacher can both assess the students' product, i.e. a poster and students' presentations, i.e. in the form of video or live streaming. Selfassessment is also possible to be done for this model. The teacher can ask 
some questions such as what the students have learned and how they feel after completing the project, and also whether the product is useful for them or not. Once the students complete this model, they are expected to both comprehend English text type and digital literacy skill, i.e. online safety.

\section{CONCLUSIONS}

This paper has discussed the needs of being digitally literate, especially for adolescent students. Thus, it presents the ideas of implementing digital literacy teaching in the English classroom through several learning activities. There are two models of learning activities proposed in this paper. The models can be used to teach English in the Indonesian education context, specifically for senior high school students based on the core and basic competence of English in the Curriculum 2013. Both infusion and dispersion approaches are somewhat appropriate for the two models. Learning activities using ICT such as microblogging and video blogging are also proposed. These activities can be done both in face-toface learning and distance learning with the use of digital devices and the internet.

The first model which focuses on building the students' awareness of fake news intends to teach a news item text for the students. Students are taught how to identify fake news and how to distinguish it from real news. The students are expected to be more digitally literate in terms of credibility of information on the internet after doing the learning activities in this model. The second model emphasizes the students' awareness of online safety. Integrating the four skills of English language, this model intends the students to create an online poster containing tips for staying safe while online. The second model focuses on the teaching procedure text in the form of tips based on the core competence in Curriculum 2013. Both distance learning and face-to-face learning are possible to be applied in this model.

Last but not least, this paper still has a limitation in terms of variety of activities. However, teachers or other practitioners may adjust the activities depending on the students' characteristics and classroom condition. The learning activities proposed in this paper, therefore, could possibly show how to teach both English and digital literacy at the same time.

\section{RECOMMENDATION FOR FURTHER STUDY}

Both research and development and action research designs are possible to be conducted based on the concept proposed in this paper. Other researchers may develop materials or media to promote digital literacy for English subject. This research is worth it due to the absence of this kind of English material. Another possible research is action research in which aims to improve a certain skill. The next researchers may investigate whether the use of digital devices and digital literacy-based activities proposed earlier can improve students' literacy skills, i.e. reading and writing.

\section{ACKNOWLEDGMENT}

This paper is included as a part of Academic Writing course in the Graduate School of Yogyakarta State University. The authors have not conducted any research since this is a literature-based paper. The opinions expressed in this paper do not reflect the position of the institution.

\section{REFERENCES}

[1] Livingstone, S., Couvering, E.V., and Thumim, N. 2005. Adult media literacy: A review of the research literature, London: Ofcom,

[2] Kemenkominfo, Selama 2016, 300 Akun Medsos Penyebar Hoax Diblokir Polisi, Available: https://kominfo.go.id/content/detail/8640/selama-2016-300-akunmedsos-penyebar-hoax-diblokir-polisi/0/sorotan_media.

[3] Ng, W. 2012. Can we teach digital natives digital literacy? Computers and Education, 1065-1078
[4] Amindoni, A. 2016. Indonesia sees drastic increase in cybercrime: Jokowi $20 \quad$ December http://www.thejakartapost. com/news/2016/09/20/indonesia-sees-drastic-increase-in-cybercrimejokowi.html.

[5] Buckingham, D. 2015. Defining digital literacy - What do young people need to know about digital media? Nordic Journal of Digital Literacy Special Issue. 21-35.

[6] McKenna M. C., Conradi K., Lawrence C., Jang B. G. and Meyer J. P. 2012. Reading attitudes of middle school students: Results of a U.S. survey, Reading research quarterly, 47(3), 283-306.

[7] U. S. I. Centre, 2017. Curriculum Planning: https://www.saferinternet.org.uk/advice-centre/teachers-andprofessionals/ curriculum-planning.

[8] Shellenbarger, S. 2016. Most Students Don't Know When News Is Fake, Stanford Study Finds https://www.wsj.com/articles/moststudents-dont-know-when-news-is-fake-stanford-study-finds$\underline{1479752576}$.

[9] Anna, L.K., 2017. Remaja Rentan Jadi Penyebar Berita Hoax, http://lifestyle.kompas. com/read/2017/09/22/161600620/remajarentan-jadi-penyebar-berita-hoax.

[10] Mike, $2017 . \quad$ Teen Internet Statistics, https://www.onlinesafetysite.com/P1/Teenstats.htm.

[11] Chabibie, H. 2017. Literasi digital sebagai tulang punggung pendidikan, http://pustekkom.kemdikbud. go.id/literasi-digital-sebagaitulang-punggung-pendidikan/.

[12] Gunderson, L., Odo, D.M., and D'Silva R. 2011. Second language literacy in Handbook of research in second language teaching and learning, New York, Routledge, 2, 472-487.

[13] Hicks, T. and Turner, K. H. 2013. No longer a luxury: Digital literacy can't wait, The English Journal, 102(6), 58-65,

[14] Hoechsmann, M. and DeWaard, H. 2015. Mapping digital literacy policy and practice in the Canadian education landscape, http://mediasmarts.ca/teacher-resources/digital-literacyframework/mapping-digital-literacy-policy-practice-canadianeducation-landscape.

[15] Bruce and Peyton. 1999. Literacy Development, International Journal, 1-27.

[16] Eshet-Alkalai, Y. 2004. Digital literacy: A conceptual framework for survival skills in the digital era, Journal of Educational Multimedia and Hypermedia, 13(1), 93-106,

[17] Karpati, A. Digital literacy in education, Moscow: UNESCO Institute for Information Technologies in Education, 2011.

[18] Rudestam, K. and Schoenholz, Read J. Handbook of online learning. Thousand Oak, CA: SAGE Publication, Inc., 2, 2010.

[19] Stommel, J. 2012. Hybridity, pt.2: What is hybrid pedagogy?: http://www.digitalpedagogylab.com/ hybridped/hybridity-pt-2-what-ishybrid-pedagogy/.

[20] Foldnes, N., 2017. The impact of class attendance on student learning in a flipped classroom, Nordic Journal of Digital Literacy, 12, 8-18.

[21] Minister of Education and Culture. 2016. Ministry Regulation Number 24 year 2016 on Core Competence and Basic Competence in Curriculum 2013

[22] Brown, H. D. 2004. Language assessment: Principles and classroom practices, While Plains, New York: Pearson Education.

[23] Fragoulis, L. 2009. Project-based learning in teaching of English as a foreign language in greek primary schools: From theory to practice, English Language Teaching, 113-119. 